\title{
Bio-objects: new conjugations of the living
}

\section{Sakari Tamminen* Niki Vermeulen**}

\begin{abstract}
Rapid advances in the life sciences have led to a radical transformation in thinking about what life is: we now compose living beings as synthetic life, from the ground up. "Life" has been multiplied and fragmented in molecular and database form and can be embodied in anything from engineered organisms through organs grown outside the body to bioprinted materials. Such new forms of life disrupt social relationships, challenge boundaries between culturally defined categories, pose new questions for governance, and reshape relations between living and ethics. Building on their earlier work with "bio objects", the authors suggest that this concept can aid greatly in mapping out and analysing the empirical spheres in which new conjugations of life are being re articulated. The paper contextualises the concept further via an examination of literature about life, and it systematically identifies key epistemic platforms through which bio-objects are brought to life today.
\end{abstract}

Keywords: Life sciences, Life, Living objects, Technologies of life, Epistemic platforms.

\footnotetext{
* University of Helsinki, Helsinki, Finland.

** University of Edinburg, Edinburg, United Kingdom.
} 


\section{Bio-objetos: nuevas conjugaciones del vivir}

\section{Resumen}

Los rápidos avances en las ciencias de la vida han llevado a una transformación radical en la idea de lo qué es vida: ahora componemos los seres vivos como vida sintética, desde cero. La "vida" se ha multiplicado y fragmentado en forma de moléculas y de base de datos, y puede adoptar configuraciones que abarcan desde organismos manipulados y órganos desarrollados fuera del cuerpo hasta materiales bioimpresos. Estas nuevas formas de vida alteran las relaciones sociales, desafían los límites entre categorías definidas culturalmente, plantean nuevas cuestiones de gobernanza y reformulan las relaciones entre la vida y la ética. Valiéndose de su trabajo anterior sobre el tema, los autores sugieren que el concepto de "bio-objeto" es útil para mapear y analizar las esferas empíricas en las que se están rearticulando nuevas conjugaciones de la vida. Este artículo contextualiza el concepto a través de una revisión de la literatura sobre vida, e identifica de manera sistemática las plataformas epistémicas clave a través de las cuales los bio-objetos cobran vida en la actualidad.

Palabras clave: Biociencias, Vida, Objetos vivos, Tecnologías de vida, Plataformas epistémicas. 


\section{Life and adding a new category of objects}

A gathering consensus in anthropology, science studies, and philosophy of biology suggests that the theoretical object of biology, "life", is today in transformation, if not dissolution. Proliferating reproductive technologies, along with genomic reshufflings of biomatter in such practices as cloning, have unwound the facts of life (Helmreich, 2011, p. 671).

n 2010, BBC Radio 4 aired A History of the World in 100 Objects. The 100-part radio show, produced by curators of the British Museum and presented by the museum's director, provided a brief outline of the history of human civilisation through key objects characterising particular eras (see also MacGregor, 2012). Rather than apply the lens of historical events, as is more typical in describing history, the producers took material objects, from early tools manufactured two million years ago to the modern-day credit card, as an entry point to discussing civilisations and their particular organisation. Thereby, individual objects were rendered as complex signals of the achievements of past civilisations. In a move that dovetails with a focus not uncommon in today's social sciences, humanities, and philosophy, the series homed in on the role of material culture and its living objects.

Many of the 100 objects were intimately connected with the cycle of life and death. Some represented reproduction and fertility, as with the Samarra wall paintings, thought to be of harem members, or the Lovers Figurine of the Ain Sakhri caves. Others were articles such as gifts and amulets to amplify the powers of the dead in their meeting with the gods of the afterlife, such as the clay armies buried alongside emperors. In addition, mummies turned the embalmed bodies of priests and rulers of Egypt into historical objects of research, each with its own complex biography decoded from hieroglyphics. Absent from the series, however, were artefacts that the curators of the British Museum will soon doubtless count among the key defining objects of the dawn of the 21st century. These objects embody an expansive narrative and powerful iconography derived from contemporary genetic models of the 'gene' and the "double helix", 
a proxy for 3D molecular structure and the script of life, both coded and laid bare. Perhaps the follow-up exhibition will display synthetic forms of life, created in labs and on artists' workbenches: predecessors to the first "booted-up" engineered organisms (Gibson et al., 2012), bioluminescent rabbits (Kac, 2000), synthetic organisms (Ginsberg et al., 2014), bioprinted organs (Vermeulen et al., 2017), and designer chairs grown into their final form (Temperton, 2015). One day, these objects may all sit behind glass in a display showcase labelled "Objects of Life" or "Bio-objects", where visitors are able to review a set of materialities, processes, and relationships representing the complexity of living creatures and their host societies today.

Let us unpack the label on that museum case. The prefix "bio" indicates life or living organisms. An object, on the other hand, is rather more fixed, a known structure of social relations, material entities, and processes. We argue in this paper that bringing these two concepts together into a new one - that of the bio-object - creates a useful framework for identifying the new things to which a sense of vitality, life, is attributed, and for investigating how they are brought among the living.

Carrying "bio-object scholarship" (Vermeulen et al., 2012; Tamminen; Vermeulen, 2012) further, this paper elaborates on the notion and contextualises it with reference to established literature. On this basis, we argue that much of what "life" was (Helmreich; Kirksey, 2010) has been reconceptualised through its materiality in various object-forms through technological endeavours and (re)engineering. We begin the discussion by reviewing the three main approaches to life-related discourse and philosophies as identified by Eugene Thacker in his book After Life (2010): life as a divine spark, life as mechanistically wired meat, and life as immanent and evolving permutations of patterns and relations. These entail three foundational discursive formations allowing for cultural articulations imbued with vital attributes, although in some cases these fall short of providing explanations for the novel forms of life generated in contemporary lifesciences labs. Having delineated these limits of current discourses, we devote the second part of the paper to addressing the need to establish new spaces of meaning for "living objects" in the 21st century, and we do just that, through further exploration of the concept of bio objects. We 
argue that bio-objects - when understood as fruit of processes of bioobjectification, or processes that make living knowable - can function as a heuristic device by which one can understand diverse life forms through a framework extending beyond the academic search for the essence of life, a framework that stresses the importance of empirically grounded social and cultural research on the materiality of new living beings.

\section{The limits of life}

Before introducing a suitable approach for considering the living and processual, we must examine the foundations from the past, in which life is a static object rather than the living and breathing. While the world is teeming with all manner of and living beings and this might tempt us to think that surely there are, accordingly, numerous conceptualisations of life, when we step back and examine Western history of thought we find a mere handful of cultural conceptualisations of the essence of life. Hence, Thacker (2005), for example, identified only three general discourses of life as having existed, grouping these under three key themes thus:

There have only ever been three approaches to thinking about life: SOUL, MEAT, and PATTERN. Within this trinity is everything deemed to be animate, living, and vital [...]. Thus, "soul", "meat", and "pattern" form a trinity. The trinity is also a triptych: soul in the center, meat on the right-hand side, and on the left, pattern. An image of thought that continuously switches, swaps, displaces, and replaces the place-holder that defines life: from psyche to mechanism and animal electricity to the "gemmules" and "pangens" to DNA and the "code of life". However, these three approaches do not form a periodization, with Aristotle's psyche followed by Descartes' clockwork body followed by the genetic code (Thacker, 2005, online).

One can create a matrix of understanding of life by following these three cultural threads through Western thought surrounding the key aspects of living (see Table 1, below).

Firstly, the idea of life-as-soul presupposes a "superlative", overflowing psyche that animates the living as an embodied being. This notion is introduced in Aristotle's treatise De Anima (1986), which describes an 
animating principle of life, a "life spirit" or divine spark. The mechanistic, biological, or organistic understanding of life, in turn, applies a materialistic understanding in which life is re-articulated in terms of opposites: life as opposed to death. This is a temporal understanding of life. The third interpretation emphasises self-organisation, patterns, and emergence as the key aspects of life, establishing an informatic framework (Thacker, 2010).

Table 1: The three key discourses of life and their relation to living, per Thacker (2005).

Note that, below, material objects of life are subsumed under the living organism

\begin{tabular}{|c|c|c|c|}
\hline Life & $\begin{array}{c}\text { Living being as } \\
\text { material articulation } \\
\text { of life }\end{array}$ & $\begin{array}{c}\text { Processes defining } \\
\text { the living }\end{array}$ & $\begin{array}{c}\text { Key relations with } \\
\text { regard to the living }\end{array}$ \\
\hline $\begin{array}{c}\text { Life-as-time, } \\
\text { "Meat" }\end{array}$ & $\begin{array}{c}\text { Living as a temporal } \\
\text { embodiment of life }\end{array}$ & Clockwork & Causal relations \\
\hline $\begin{array}{c}\text { Life-as-form, } \\
\text { "divine soul" }\end{array}$ & $\begin{array}{c}\text { Living as the enunciated } \\
\text { idea of the divine }\end{array}$ & $\begin{array}{c}\text { Parallel } \\
\text { processes }\end{array}$ & $\begin{array}{c}\text { Transcendental relations } \\
\text { between life and living }\end{array}$ \\
\hline $\begin{array}{c}\text { Life-as-spirit, } \\
\text { "immanent pattern" }\end{array}$ & $\begin{array}{c}\text { Living as a material } \\
\text { platform for life's } \\
\text { objects }\end{array}$ & $\begin{array}{c}\text { Emerging informatic } \\
\text { patterns }\end{array}$ & $\begin{array}{c}\text { Emerging, } \\
\text { immanent relations } \\
\text { between scales of } \\
\text { phenomena }\end{array}$ \\
\hline
\end{tabular}

Source: Developed by the authors, based on Thacker (2005).

Thacker (2010, p. 250) summarises the three approaches as involving "Il]ife-as-time, life-as-form, and life-as-spirit. Perhaps, given the persistence of these three approaches, we can abbreviate them even further: life is always 'meat' (the thickness, the facticity of life), 'soul' (the formal principle of the creation of life), or 'pattern' (the intangible plane of organization running throughout life)". Clearly, each of the discourses is bundled with its own way of conceptualising life, and contemporary reflections on life are often situated along one of these historical trajectories, which stretch back to particular theological, philosophical, and scientific backgrounds. At the same time, these foundational discourses impose specific borders to understanding that condition how new forms of life can be understood. By characterising it as imagined, engineered, or remixed, they limit the 
cultural diagnostics applied to ongoing transformations at the nexus of contemporary bioscience and society.

The challenge these discourses thereby set for understanding "life" is a beast with philosophical, methodological, and political heads. Thacker (2010, p. 250) describes the challenge for

reflection on the concept of life [as] not about the most accurate or coherent definition of life. Life as a concept quite effortlessly passes between the poles of reductionism and mysticism - life can be defined down to the molecular level, at the same time that the notion of the irreducibility and mystery of life raises the concept up to existential and spiritual levels. Instead, the major challenge for any ontology of life lies in being able to think its very conditions of being thought at all.

"Life", and with it the sphere of the living as a material articulation of the idea of life, becomes a challenge for reflective thought in the search for ontological grounding.

\section{Lifeless life and living objects}

The next step in peeling back the layers of how the living is rendered in the object of enquiry thought of as life is to consider how contemporary scientific understanding relocates all encompassing "life". Three specific metaphors are employed, all stemming from the idea of the "informational pattern": those of the molecule, information, and the script. All of them are derived from the overarching metaphor of a computer (conflating the mechanistic "clock" and more ephemeral "information" into a single figure) and the decoding and re-encoding software run on it (e.g., Keller, 2000; Brenner, 2012). The movement away from the organism to molecules, then from molecules to information, and from information to prescriptive script - as separate entities and not necessarily tied to any specific organism or its body - is nicely captured by the following excerpt from Richard Doyle's analysis of the rhetoric of late-20th-century life sciences:

[T]he object of biology has somehow been displaced, with the molecule overtaking or territorializing the organism and getting plugged into the computer [...] [W]e never really knew what we were talking about [and] then we were 
talking about life [...] [T]he pull of the desire to know what life is both founds and embarrasses the life sciences (Doyle, 1997, p. 1).

What has happened to life as an analytical object of social inquiry based on the advancement of biosciences and the material transformation brought about by biotechnologies? It seems that the body as a unit of analysis has now given way to molecules that contain the code for life, and that information technologies have captured life's vitality and transformed it into bits. This has had the effect that the thingness of Life with the capital $L$ has undergone a technological copy-paste virtual framing (Gestell). As Heidegger (1993, see also Heidegger, 1977) was afraid - life as a metaphysical grounding force has been sucked dry of its essence and life in itself no more creates anything new in the world. Thus, the idea of life as a scientific object of analysis has been peeled away like an onion, layer by layer, only to lead to the conclusion that the essence of "life" perhaps does not reside exclusively within any specific body: DNA is an instruction set beyond specific bodily forms, not "life itself", but rather a component of life though, as purely informational, also "lifeless".

At the same time, the existence of vast multitudes of what are often termed "living beings" - at scales from the intracellular to macro-organisms - may never have been more positively affirmed by the life sciences. The science of life, biology, has become the key enabler driving innovation and massive-scale international business in the agriculture, food, and pharmaceutical domains (Jasanoff, 2010; Mittra, 2016). Within this context, at a cultural moment sometimes referred to as the era of "Big Biology" (Vermeulen, 2016), not only is biologically framed existence confirmed and exploited, but novel biological entities performing new forms of labour and enacting social relations are systematically being created through new biotechnologies (Pálsson, 2009; Prainsack; Buyx, 2017). On top of this, new biologically inspired aesthetic forms (bio-art), ethics concerns, and counter cultural approaches to bio-innovation (principally bio-punk) attest to the sighting of bio objects never before seen on Earth (e.g., Ginsberg et al., 2014). 
Consequently, vital essence is multiplying in its forms and flowing to animate a multitude of living beings, as is characterised by Thacker (2010) and Helmreich (2011). The construct of life, referring to a transcendental field from the time of Aristotle to Deleuze - whether understood as soul, meat, or pattern - must give way to the immediacy and materiality of the living beings (Schrödinger, 1944; Venter, 2012). In the traditional concepts of life, the boundaries were between self-contained organisms that can "naturally" procreate, with new varieties and species being created through cross-breeding; however, bioengineering has cast such boundaries to the side, opening the path to (targeted) genetic change of organisms (in the form of GMOs and more recently gene editing). Species boundaries too have gained new definitions through genetics work, leading to new ideas of individual species and their scope (e.g., specimens of certain grasses and fungi previously perceived as individuals now appear to be part of larger organisms). These new understandings have given rise to re-imagination of the tree of life. Even the boundary between life and non-life is directly challenged, through synthetic biology's artificial creation of life.

While all things flow from rather slippery vital essence, we cannot stop there. If thinking and our perception starts and ends with objects, then, as Merleau-Ponty ([1945] 2012) noted, we (particularly as students of the philosophy and social and cultural forms of bioscience and its development) should be concerned with what possible conceptual and materially perceived forms living objects take, or might assume, in today's biosciences. Amidst the above-mentioned breaching of boundaries that once seemed selfevident, this entails translating the most basic first questions about life into questioning the practices observed in the life sciences and beyond, on both their conceptual and material dimensions, as life is brought to previously non-existent objects. Rather than the essence of life, today's question is centred on the observed forms of living entities. Similarly, a shift is due from purely philosophical ponderings of the possibilities for the existence of life toward multiple ontologies (Mol, 2002) and new forms of the living multiplicity.

This growth, from a small number of discourses about "Life" into celebration of multiplicity manifested in countless forms of living entities 
and their processes, brings a scientific and moral imperative to arrange and standardise in a manner befitting the multiplicity, thereby rendering it knowable and available to pursuit of a variety of objectives. Such efforts are visible in global work to standardise "bio ontologies"1, living objects and their standardised relations (e.g., with bio-banking standards; see Tamminen, 2015), political closure to bio ethics debates, ethics guidelines (Dimond; Stephens, 2018), etc. In these endeavours, what once was an ephemeral "life" concept made use of through a limited set of cultural discourses is now, in techno-scientific practice, being objectified through living entities in "standardisation machines" having various shapes and powers. Some of these entities have entered our lives already - for instance, via commercial routes of genetically modified organisms enabled by current bioengineering platforms - while others are imaginary living entities enabled and objectified by simulation of the complexity of life within computers. For example, physiologists, molecular biologists, biochemists, biophysicists, engineers, mathematicians, and computer scientists all come together in systems biology through their efforts to model life (Vermeulen, 2018).

\section{Defining bio-objects as conjugations of the living}

We have argued that the emergence of bio-technologically enabled bio-objects has re articulated "life" via new fleshy formats, which are given context within new types of discourses beyond philosophy and biology proper. In light of this, we find the concept of bio-object to hold great potential as a tool for reorienting the gaze of social scientific research and cultural critique to empirical matters of concern in bio-technology infused global societies today. What is a bio-object then?

Firstly, bio-objects embody configurations of material substance to which "living" is attributed, and the notion of bio-objectification, in turn, refers to the processes in which the status "living" is acquired. Methodologically, the identification of bio-objects follows empirical practices and accounts

1The bio-ontology mission is described thus at www.bioontology.org: "Our vision is that all biomedical knowledge and data are disseminated on the Internet using principled ontologies in such a way that the knowledge and data are semantically interoperable and useful for furthering biomedical science and clinical care". 
wherein that status is assigned to certain entities that through this attribution are designated as recognised, known living beings. The approach applied to identify bio-objects is similar to following the ethnomethodological principle of using actors' point-of-view on action, and it can be likened also to application of Latour's "follow-the-actors" principle whereby the outcome of a followed activity is a bio-object (Garfinkel, 2002; Latour, 2005).

From a methodological standpoint, the two formulations ultimately point to the same objects of analysis. These are new types of conjugations in the sphere of the living, or concrete objectifications of the vital matter at hand. It should be noted at the outset that with the concept of the bioobject we do not intend to reduce life to a material entity, a mute object lacking agency. Rather, by questioning the status of living objects crafted by current biosciences and their technological innovations, we strive to emphasise the constant interplay of life with novel techniques aimed at rerouting, diversifying, collecting, and commodifying the vital processes. This is the process we call bio-objectification. Bio-objects cannot be reduced to any pure form preceding them; rather, their epistemic platforms (discourses and the practices surrounding them) are grounded in a network of unstable ontologies generated by the empirical activities that form those epistemic platforms. These are ongoing processes, some slower and more permanent and others being faster, fickle ones, that essentially generate bio-objects as temporal becomings rather than give them a stable form of being. This methodological standpoint shows some similarity to the perspective from which 'living' is an autonomously evolving or self emanating phenomenon - "autopoiesis" (Maturana; Varela, 1991) or "that which is capable of error" (Canguilhem, 1994) - but it should not be read as a theoretical position or a predisposition toward any preferred ontology of life. This acknowledgement is meant to signal, very much to the contrary, a stubborn methodological resistance to take any single type of objectification encountered found in philosophy's or the life sciences' theories of life (whether life as mechanistic system, replicating code, or materialisation of a vital spark) as a privileged methodological starting point for social or cultural analysis.

In terms of methodology, then, empirical research on bio-objects and bio-objectification finds the objects of life and related processes contesting 
the boundary lines drawn between entities we have grown accustomed to taking for granted as existing by themselves and for themselves. This is most evident in experimental models of hybrid forms of life, or genetically modified organisms (Holmberg; Ideland, 2012; Brown, 2012; Hansen, 2012). ${ }^{2}$ Objects of life, especially when embedded in 21st-century global techno-capitalism, are reworked forms of "nature" (Franklin, 2000) and networked as never before as components of emerging forms of technoscientific enterprises.

Secondly, bio-objects are living, not "Life". Bio-objects can be situated as ongoing sensemaking projects between, on one hand, entities that were once considered "pure" substances making up particular, discrete forms of living entities and, on the other, more fluid, conceptually hard-to-pin-down living entities such as genetic resources, stem cells, and synthetic forms of life.

Today, "Life" should not see as a noun. Instead, it is a verb and its conjugations (see Kelly, 1994, Helmreich, 2007). In consequence of these new configurations, emerging bio-objects question, destabilise, and in some cases re-establish boundaries between human and animal, organic and inorganic, living and suspension of living, time and space, subject and object, agency and effect. In turn, there are boundaries around the bio-object concept, distinguishing between subtle and diffuse relations among object, bio-object, and subject. You can see this, for instance, when considering water as a bio-object or examining the construction of a patient as a process of bio-objectification (Zeiss, 2012; Douglas, 2012). The epistemic and practical complexities stemming from considering water as a living object, or the practices of turning patients into objects of intervention, reveal how there is no "Life" but a multitude of objects constituting what we call living, the true objects of knowing and intervening in observable practice.

\footnotetext{
${ }^{2}$ Among the examples we draw on here are forms cited in the first bio-object book, which was output from a European Marie Curie training network led by the University of York STS unit's Andrew Webster in 2002-2005 and in a series of related annual meetings from 2007 onward. The network subsequently obtained additional funding through a European COST Action (2010-2014), which resulted in various projects and publications elaborating on the notion of bio-objects (e.g. a series of bio-object-related articles in the Croatian Medical Journal and a recent special issue on biobanking, see Stephens et al., 2018).
} 
Thirdly, the "newness" of emerging bio-objects should be considered an immanent feature of the particular epistemic culture under analysis. "Newness" denotes an epistemic break in knowing, representing, or intervening in life in its objectified, materially and socially consolidated form.

Particular instances or collections of matter become vital in, and for, various practices and knowledge regimes, which by the same token make life matter. From a historical perspective, the field of biology is quite recent, as Foucault ([1966] 1973) famously argued. What we are currently witnessing, however, is that "life" as an object of research, intervention, and innovation is increasingly represented through an idiom of science and its regime of truth - not just in academic literature but also in science communication aimed at different publics. Several contemporary scholars (e.g., Rose, 2007) even claim that humanity has crossed a threshold to life being manageable entirely through its "molecularization/genetization" by dint of revolutionary developments in scientific understanding of life's basic components coupled with the advent of technologies capable of representing and modifying them (e.g., molecular structure and genetic engineering, respectively). In short, the argument is that the total "objectification" of life has come about through breakthroughs in scientific knowledge and related representation and intervention techniques.

While the "molecularization/genetization thesis" certainly holds true in and for certain epistemic cultures (Knorr-Cetina, 1999) of our technoscientific modernity (such as bio medical research communities), the materialities and processes of life are not so clear-cut in other communities, let alone for all actors involved. In fact, the argument of molecularisation of life flirts dangerously with essentialisation of life into molecules and DNA: reductionism in which the meaning of living and materialities of life are bounded by contemporary biological thinking. In this particular objectification, molecular knowledge is the truth of life, the way of knowing, and the way of intervening in the realm of "life itself" - an objectification that, borrowing from the given epistemic culture and its explanatory resources, turns the "thing" of life into an object of molecular essence.

We aim to resist the lure of this overly reductionist thesis by examining in detail the ways in which life is made an object in different settings, both in and 
outside the discourse of contemporary biosciences. The various life forms and their cultural forms of "being alive" become objects of knowing, representing, and intervening in a myriad of ways for which the molecularisation thesis is suitable, but because they encompass molecularisation as one of the key processes of our time. New forms of living are simultaneously created via and generative of social, political, economic, and philosophical questions about life as an object of enquiry.

Fourthly, bio-objects are experimental forms of life, where "experimental" should be taken to refer not only to site-specific, spatially contained local achievements (e.g., in a laboratory) but also to an embodiment of generative relations transcending previous categories of representation and collective practices.

For instance, debates on IVF embryos in Germany at the dawn of the 21 st century interweave techno-scientifically assisted creation of life and related relations of love and loving, thereby giving birth to a new bioobject, a love-embryo, or the "fruit of love" (Bock von Wülfingen, 2012). This experiment has echoes elsewhere but is conditioned by culture and nation; parallel patterns are not found elsewhere overall. Along similar lines, an analysis of the regulation of IVF embryos and related research practices in the UK and Italy shows that, notwithstanding considerable ongoing debate about globalisation and the erasure of national boundaries, the state in its traditional form is still highly potent in shaping matters of life (Metzler, 2012). Across the whole reproductive field, regulation varies hugely between countries, generating also different paths and possibilities for the emergence of embryos in their political, biological, and economic forms. Therefore, these paths, or bio-objectification processes, conditioned by states through rules and regulation, should be seen as performative in the epistemological, ontological, and economic sense alike.

When we zoom in on research practices, the lens of bio-objects reveals, for example, virtualising life and rendering it inanimate. When creating a silicon cell, scientists take the life-as-information paradigm to an extreme: understanding life as information by employing coding to detach actual biological matter from its principles of operation while recoding the functions on a silicon chip (Vermeulen, 2012). In this process, the "cell" 
as an object of life undergoes a radical transformation from organic into virtual form. And, while much of the philosophical tradition of the West has defined life as animation, current practices of cryopreservation are able to suspend - not destroy - life, keeping its vitality potent for some time (Tamminen, 2012). Through the development of various life-management technologies and practices, life has become frozen, and these processes of bio-objectification, playing with the boundary between life and non-life, have successfully stretched the attribution of life and vitality to inanimate objects. Moreover, said processes of transforming life are both generated by and generative of (international and more local) relations. These display deep interconnections of life, science, economy, politics, and culture.

\section{The bio-object as a tool for critical thinking}

When the concept "object" is utilised in a very broad sense to refer to materialities, processes, and relations (Holmberg et al., 2011; Tamminen; Vermeulen, 2012) and the qualifier "bio" is added, we arrive at a particular conceptual frame that affords talking about these vital objects. We suggest that, even if life is ubiquitous on our planet (and perhaps elsewhere), concepts are not. Concepts and interventions related to anything we call life are always specific, and in that specificity, they are actually quite few. A rarefying principle indeed obtains with the concept of the bio-object - not everything is considered life, or at least considered life that matters so much that it becomes stabilised as an object to be represented, interfered with, or remodelled. Hence, bio-objects are not vaguely defined things. Instead of being just anything or "the most compelling name for that enigma that can only be encircled and which the object (by its presence) necessarily negates" (Brown, 2001, p. 7), bio-objects have a presence and exist in a particular relationship with life and processes of objectification. We reiterate that this does not entail recourse to an essentialising notion of "object". Rather, it suggests that these objects both materially and socially are specifically ordered forms of mattering living. This renders the definition distinct from one in which bio-objects might be a mere 'thing' without material (internal) or social (external) order (as transcendental musings would have it). Internal 
and external modes of ordering are always relational processes that can be traced in various empirical conditions.

In their materiality, all objects are generative of and constituted through a set of relations, whether inside or outside the lab. Consequently, the main questions in addressing bio objects revolve around materiality and the discursive relations in which the objects are embedded. By exploring the materiality of bio-objects, we point to how they challenge, change, or reify social boundaries, alongside how cultural boundaries across and within established categories of the living are questioned in relation to biological truths. By exploring bio-objects in terms of relations, we suggest that social, cultural, economic, and political relations are at the core of the generation of bio-objects and the processes by which they come to be known, debated, and conjugated.

All this is to say that bio-objects do not emerge from nowhere, nor do they operate in a vacuum. They are always embedded in a historically shaped web of current discourses of life and living, while at the same time the generative effects of newly formed bio-objects allow us to focus on the re-configured relations between (previously) discrete domains to make sense of where life might be headed.

\section{Conclusions, towards (re)capturing bio-objects}

With this paper we have taken current "bio-object scholarship" further, fleshing out and contextualising the idea of the bio-object, in line with the argument that much of what "life" once was (Helmreich; Kirksey, 2010) has become reconceptualised through its materiality in various object forms through technological enquiry and (re)engineering. After setting the scene by charting out the ways in which "life" and "the living" are changing (in various manifestations between lifeless life and living objects), we can confidently state that their vast multiplicity enables diverse reflections and approaches to studying what is claimed to fall within the realm of the living. This is a far cry from what came before: the three dominant approaches to discourse and philosophies of life suggested by Thacker, with their attendant foundational discursive platforms allowing for cultural articulations of objects imbued with vital attributes. The traditional underlying cultural philosophies, with 
the specific conditions they impose to understand new forms of life, are not always suited to explaining novel life forms generated in today's labs. Consequently, traditional ways of articulating the meaning and function of life lead to conceptual conundrums and can restrict or stall discussion, a new concept is necessary, to account for and encourage progress of thought.

The need to address the limits of earlier discourses by generating new spaces of meaning for "living objects" in the 21st century can be met via the concept of bio-objects. We propose that the emergence of bio-technologically enabled bio-objects creates distinct epistemic spaces for articulating and objectifying "life" in its new fleshy formats. Although bio-objects still are brought to life and shaped by existing discourses on the ontologies of life, we argue that contemporary bio-objects can be mapped through their epistemic platforms that reveal the disruptive effects on moral, economic, social, and material terrain where they are framed as novel matters of concern. This mapping can be achieved by anchoring the analysis to the three key cultural philosophies of life and their discursive arrangements, with attention to how they shape emergent bio-objects in relation to the spaces (labs, society, economy, politics, etc) within which bio-objects are brought to life and become potent enough to destabilise current cultural orders. We claim that this approach affords painting a picture of the large-scale effects of novel knowledge-practices brought to our social and cultural worlds by life sciences. The concept of bio-object can thus be used to reinvigorate social research focused on the biotechnological present, without unnecessary recourse to either transcendental, mechanistic or information-based understandings of "life". This should enable a more analytically oriented and accurate conceptually anchored understanding of the key matters of concern in our contemporary dealings with life.

How the processes of objectification take place in particular contexts is an empirical question. In this connection, the "bio-object" concept becomes a tool to study the newly found effects of novel life forms in their relation to various aspects of society. Bio-objects should always be considered outcomes of surrounding practices and socio-cultural discourses that situate them within particular epistemic arrangements - not living things in their own right that stem from a transcendental ontological sphere. These contextual 
arrangements of material, economic, political, and ethical relations are the platforms necessary for breeding feasible and viable bio-object generation. As these generative platforms root the bio-objects in particular empirically witnessed ontologies, the introduction of the concept is not a call to redefine the essence or ontology of life in any particular way - e.g., by introducing a master concept that encapsulates life over time, the form and structure of organisms, or self-immanent transcendence by vital forces. ${ }^{3}$ Instead, the notion of bio-objects is an invitation to reimagine the ways in which social sciences and cultural theory approach the question of Life and living beings methodologically in empirically situated contexts, in an era of burgeoning biotechnological capacity to intervene in the realm of "Life" and the living, an era of topped-up biopower. The concept calls us to question what precisely those empirical socio-cultural practices and discourses are that lurk behind the idea of "life-as-a-script", "life-as-information", and "life-asmolecules" - to recognise and address the conditions of possibility informing our thinking about life and how they continue to shape our sphere of living.

In empirical terms, the scope we tentatively suggest for the concept covers products of biological manufacture enabled by technologies of life - in particular, new-object-enabling technologies such as novel laboratory practices, bioinformatics/computing, GMOs' creation, cryogenic technologies, and synthetic biology alongside the relationship work that goes into the "objectification" of the end results of these technologies (Vermeulen et al., 2012). This empirical scoping points to the abovementioned transition from analysis to intervention that the tool affords, and the word itself, in combining "bio-" with the "object" structure, indicates potential usefulness in identifying the new things to which vitality, life, is attributed and investigating how they turn into objects of this sort in their living sense. However, for the concept to serve as a critical thinking tool and general approach rather than "another theory" of the essence of life, what can be said about the process and embedded relations in which the living things in all their variety become objects? We find that specific epistemic platforms exist where bio-objects currently emerge. One can study their

${ }^{3}$ Even if the current academic interest in metaphysical speculation abound ('new materiality studies', 'speculative realism', object-oriented ontology; see Shaviro, 2016; Harman, 2018). 
contextual emergence and the key conditions of possibility for thinking about life today in terms of the following platforms:

- Epistemic platform 1: Bio-objects framed as new living products of biological manufacture that are enabled by technological developments. Here, particular new technologies (bioinformatics/computing, cryogenic technologies, synthetic biology, etc.) enable (re)new(ed) objectified instances of the living;

- Epistemic platform 2: Bio-objects framed as functional implements of human and/or animal bodies, in terms such as "re-gen", "trans", and "synth", along with new relations of regenerated and re-configured bodies;

- Epistemic platform 3: Bio-objects in unidentifiable social roles outside conventional relations, connected with categorisation problems and with new combinations of accepted categories, such as hybrid bio-objects, that contest old ones. These bio-objects become subject to ethical and political debate when introduced in the societal realm;

- Epistemic platform 4: Bio-objects in political debate and within discourses of their symbolic role derived from ethics and categories of "good", encompassing contested social relations, descriptions of destabilised social fabric, and processes utilised for resolution;

- Epistemic platform 5: Bio-objects framed as goods traded in global and/or local bioeconomies. Objectification of the living is performed under discourses of hope, hype, and expectations of the bioeconomy and its circuits mediating transactions;

- Epistemic platform 6: Bio-objects in mediating the performance of personal identity and the community through material or virtual records pertaining to social relations (e.g., biosociality in Web 2.0) - new relations beyond objects of life.

These epistemic platforms provide a solid contextual starting point for analysing bio-objects and for understanding new conjugations of the living. Via all six routes, bio-objects can be identified and rendered methodologically approachable without the need to resort to some transcendent notion of 'life itself' as the starting point for analysis, while new framings and roles of living matter emerge, together with corresponding generative relations. At the same time, this approach allows opening many new lines of enquiry 
into what these new objectifications of the living are made to perform on particular platforms of contemporary bioscience culture (see Tamminen; Deibel, 2018) while remaining able to reflect critically on the social and cultural role of the living in the context analysed.

Sakari Tamminen holds a PhD in Social Psychology and Anthropology of Science. He is a research fellow at the Department of Social Psychology in the University of Helsinki.

$\equiv$ sakari.tamminen@helsinki.fi

Niki Vermeulen holds a PhD in Science and Technology Studies from Maastricht University, The Netherlands. She is a Senior Lecturer at the Science Technology and Innovation Studies Department in the University of Edinburg.

Ð Niki.Vermeulen@ed.ac.uk 


\section{References}

1. ARISTOTLE. The complete works of Aristotle: the revised Oxford translation. Oxford: Oxford University Press, 1986.

2. BOCK VON WÜLFINGEN, Bettina. The fruit of love: the German IVF-embryo turning from abject into bio-object. In: VERMEULEN, Niki et al. (Eds). Bioobjects: life in the 21st century. London: Routledge, 2012, p. 137-50.

3. BRENNER, Sydney. History of science: the revolution in the life sciences. Science, v. 338, n. 6113, p. 1427-8, 2012.

4. BROWN, Bill. Things. Chicago: University of Chicago Press, 2001.

5. BROWN, Nik. Beasting biology: interspecies politics. In: VERMEULEN, Niki et al. (Eds). Bio-objects: life in the 21st century. London: Routledge, 2012, p. 71-84.

6. CANGUILHEM, Georges. A vital rationalist: selected writings from Georges Canguilhem. New York: Zone Books, 1994.

7. DIMOND, Rebecca; STEPHENS, Neil. Legalising mitochondrial donation: enacting ethical futures in UK biomedical politics. London: Palgrave, 2018.

8. DOUGLAS, Conor. Bio-objectification of clinical research patients: impacts on the stabilization of new medical technologies. In: VERMEULEN, Niki et al. (Eds). Bio-objects: life in the 21st century. London: Routledge, 2012, p. 59-70.

9. DOYLE, Richard. On beyond living: rhetorical transformations of the life sciences. Stanford: Stanford University Press, 1997.

10. FISHER, Erik. Lessons learned from the ethical, legal and social implications program (ELSI): planning societal implications research for the National Nanotechnology Program. Technology in Society, v. 27, p. 321-8, 2005.

11. FOUCAULT, Michel. The order of things: an archaeology of the human sciences. New York: Vintage, [1966] 1973.

12. FRANKLIN, Sarah. Life itself: global nature and the genetic imaginary. In: FRANKLIN, Sarah; LURY, Celia; STACEY, Jackie. Global Nature, Global Culture. London: SAGE, 2000.

13. GARFINKEL, Harold. Ethnomethodology's program: working out Durkheim's aphorism. Oxford: Rowman \& Littlefield, 2002.

14. GIBSON, Daniel et al. Creation of a bacterial cell controlled by a chemically synthesized genome. Science, v. 329, n. 5987, p. 52-6, 2010.

15. GINSBERG, Alexandra D. et al. Synthetic aesthetics: investigating synthetic biology's designs on nature. Cambridge: MIT Press, 2014.

16. HANSEN, Janus. Comparing public engagement with bioobjects: implementation of the EU co-existence regime for GM crops in Denmark, UK and Germany. In: VERMEULEN, Niki et al. (Eds). Bio-objects: life in the 21st century. London: Routledge, 2012, p. 85-101. 
17. HARMAN, Graham. Object-oriented ontology: a new theory of everything. London: Pelican Books, 2018.

18. HEIDEGGER, Martin. The question concerning technology, and other essays. New York: Garland Publishers, 1977.

19. HEIDEGGER, Martin. Basic writings: Martin Heidegger. London: Routledge, 1993.

20. HELMREICH, Stefan. What was life? Answers from three limit biologies. Critical Inquiry, v. 37, n. 4, p. 671-96, 2011.

21. HELMREICH, Stefan; KIRKSEY, S. Eben. The emergence of multispecies ethnography. Cultural Anthropology, v. 25, n. 4, p. 545-75, 2010.

22. HOLMBERG, Tora; IDELAND, Malin. Challenging bio-objectification: adding noise to transgenic silences. In: VERMEULEN, Niki et al. (Eds). Bio-objects: life in the 21st century. London: Routledge, 2012, p. 13-26.

23. HOLMBERG, Tora; SCHWENNESEN, Nete; WEBSTER, Andrew. Bio-objects and the bio-objectification process. Croatian Medical Journal, v. 52, n. 6, p. 740-42, 2011.

24. JASANOFF, Sheila (Ed.). Reframing rights: bioconstitutionalism in the genetic age. Cambridge: MIT Press, 2011.

25. KAC, Eduardo. GFP Bunny (artwork). 2000. Available at: http://www.ekac. org/gfpbunny.html\#gfpbunnyanchor.

26. KELLER, Evelyn Fox. The century of the gene. Cambridge: Harvard University Press, 2000.

27. KELLY, Kevin. Out of control: the new biology of machines, social systems, \& the economic world. New York: Basic Books, 1995.

28. KNORR-CETINA, Karin. Epistemic cultures: how the sciences make knowledge. Cambridge: Harvard University Press, 1999.

29. LATOUR, Bruno. Reassembling the social: an introduction to actor-network theory. Oxford: Oxford University Press, 2005.

30. MACGREGOR, Neil. A history of the world in 100 objects. London: Penguin, 2012.

31. MATURANA, Humberto; VARELA, Francisco. Autopoiesis and cognition: the realization of the living. Dordrecht: D. Reidel Publishing, 1991.

32. MERLEAU-PONTY, Maurice. Phenomenology of perception. London: Routledge, [1945] 2012.

33. METZLER, Ingrid. On why states still matter: in vitro fertilization embryos between laboratories and state authorities in Italy. In: VERMEULEN, Niki et al. (Eds). Bio-objects: life in the 21st century. London: Routledge, 2012, p. 151-70.

34. MITTRA, James. The new health bioeconomy: R\&D policy and innovation for the twenty-first century. London: Palgrave Macmillan, 2016. 
35. MOL, Annemarie. The body multiple: ontology in medical practice. Durham: Duke University Press, 2002.

36. PÁLSSON, Gísli. Biosocial relations of production. Comparative Studies in Society and History, v. 51, n. 2, p. 288-313, 2009.

37. PRAINSACK, Barbara; BUYX, Alena. Solidarity in biomedicine and beyond. Cambridge: Cambridge University Press, 2017.

38. ROSE, Nikolas. The politics of life itself: biomedicine, power, and subjectivity in the twenty-first century. Princeton: Princeton University Press, 2007.

39. SCHRÖDINGER, Erwin. What is life? Cambridge: Cambridge University Press, 1944.

40. SHAVIRO, Steven. The actual volcano: Whitehead, Harman, and the problem of relations. In: BRYANT, Levi et al. (Eds). The speculative turn: continental materialism and realism. Melbourne: re.press, 2011, p. 279-90.

41. STEPHENS, Neil; BROWN, Nik; DOUGLAS, Conor. Biobanks as sites of bioobjectification. Life Sciences, Society and Policy, v. 14, n. 6, 2018.

42. TAMMINEN, Sakari. Still life? Frozen gametes, national gene banks and re configuration of animality. In: VERMEULEN, Niki et al. (Eds). Bio-objects: life in the 21st century. London: Routledge, 2012, p. 203-18.

43. TAMMINEN, Sakari. Bio-objectifying European bodies: standardisation of biobanks in the biobanking and biomolecular resources research infrastructure. Life Sciences, Society and Policy, v. 11, n. 13, p. 103-27, 2015.

44. TAMMINEN, Sakari; DEIBEL, Eric. The biopolitics of information: recoding life. London: Routledge, 2018.

45. TAMMINEN, Sakari; VERMEULEN, Niki. Bio-objects and generative relations. Croatian Medical Journal, v. 53, n. 2, p. 198-200, 2012.

46. TEMPERTON, James. Beautiful, fully-formed furniture can be grown from trees. WIRED, Apr. 9, 2015. Available at: https://www.wired.co.uk/article/fullgrown-furniture.

47. THACKER, Eugene. Biophilosophy for the 21st century. CTheory, "1000 Days of Theory", td014, June 6, 2005.

48. THACKER, Eugene. After life. Chicago: University of Chicago Press, 2010.

49. VENTER, J. Craig. What is life? A 21st century perspective (a lecture on the 70th anniversary of Schrödinger's lecture at Trinity College, Dublin), 2012. Available at: <https://www.edge.org/conversation/what-is-life> .

50. VERMEULEN, Niki. Growing a cell in silico: on how the creation of a bioobject transforms the organisation of science. In: VERMEULEN, Niki et al. (Eds). Bio-objects: life in the 21st century. London: Routledge, p. 171-86, 2012.

51. VERMEULEN, Niki. Big biology: supersizing science during the emergence of the 21st century. NTM Journal of the History of Science, Technology and Medicine, v. 24, p. 195-223, 2016. 
52. VERMEULEN, Niki. The choreography of a new research field: aggregation, circulation and oscillation. Environment \& Planning A, v. 50, n. 8, p. 1764-84, 2018.

53. VERMEULEN, Niki; TAMMINEN, Sakari; WEBSTER, Andrew (Eds). Bioobjects: life in the 21st century. London: Routledge, 2012.

54. VERMEULEN, Niki et al. 3d bioprint me: a socioethical view of biofabrication. Journal of Medical Ethics, v. 43, p. 618-24, 2017.

55. ZEISS, Ragna. Water - an exploration of the boundaries of bio-objects. In: VERMEULEN, Niki et al. (Eds). Bio-objects: life in the 21st century. London: Routledge, p. 43-59, 2012. 